\title{
The Organizational Commitment Analysis of Academic Staffs: A Case Study at the Faculty of Economics, Universitas Prof Dr Moestopo (Beragama), Indonesia
}

\author{
Zulhawati $^{1}$ and Meiliyah Ariani ${ }^{2}$ \\ ${ }^{1}$ Faculty of Faculty of Business and Information Technology, Universitas \\ Teknologi Yogyakarta \\ Kampus Jombor, Yogyakarta, Indonesia \\ ${ }^{2}$ Faculty of Economics, University of Prof. Dr. Moestopo (Beragama), Jakarta, \\ Indonesia \\ zulhawati@uty.ac.id,meiliyah_ariani@dsn.moestopo.ac.id
}

\begin{abstract}
Global competition moves more quickly and requires fitting strategies along with the presence of increasingly sophisticated technological developments. Primarily, the problem is how to turn human resources into assets with excellent competitiveness. This study is oriented on the development of human resource management. In this regards, a university becomes a springhead in the management of human resources. Represented by the Faculty of Economics, Universitas Prof Dr Moestopo (Beragama), Indonesia is selected as the subject of the study, to improve the competitiveness through increased performance. There are many factors adopted by some experts associated with the improved organizational performance; yet in this case, various limitations are observed as well. The organizational commitment is selected as the object of the study. Several literatures support the topic of organizational commitment. Some of the factors influencing lecturers' organizational commitment are the transformational leadership style, interpersonal communication, and job satisfaction. The method of the study uses the application of "TEV" quantitative analysis model based on a decision tree analysis (weighting) using the expected-value formula. The results of the study have an impact on the policy that is based on the transformational leadership style; interpersonal communication, and job satisfaction. The results conclude that the lecturers' commitment on the organizational body of the Faculty of Economics, Universitas Prof Dr Moestopo (Beragama), Indonesia is high. Moreover, the effort to improve the performance to be "extremely high" focuses on the operational indicator of job satisfaction.
\end{abstract}

Keywords: Interpersonal communication; Job satisfaction; Organizational commitment; Transformational leadership style

\section{Introduction}

In the global competition, many factors must be taken into consideration, observed, and empowered so that the products (goods and services) made by the company are competitive. Human resource, as the core product of a company, is a major factor that decides the competitiveness of a company [1]. A university, represented by diverse faculties, is in this context a company that bears an important role to produce good quality human resources to win the competition. Various types of business activities demand high-quality human resources, which in general are produced by public universities-due to the fact that they have excellent facilities or infrastructure, since they are supported by the government [2]. Consequently, since they do not have similar support from the government, private universities, such as Universitas Prof Dr Moestopo (Beragama), 
Indonesia, are forced to work harder to improve the performance of their organization. Universitas Prof Dr Moestopo (Beragama), Indonesia has four faculties, i.e. the Faculty of Dentistry, Faculty of Social and Political Sciences, Faculty of Economics, Faculty of Communication; and a Graduate Program. The four faculties and graduate program bear the tasks requiring serious attentions and fitting strategies to improve organizational performance and create competitive, eligible human resources. Lecturers as the human resource must have excellent credibility and ability to support the improvement of the organizational performance quality. Competence, motivation, job satisfaction, and capability of lecturers will greatly affect their performance and automatically contribute to that of the faculty. The components of assessment in improving the quality of lecturers' achievement are the quality and quantity of work, discipline, ability to work, initiative, responsibility, and cooperation in teamwork. The common problem occurring when a lecturer has been appointed as full-time lecturer is that he/she lacks or has less commitment to support the organization.

Each organization expects the best performance from their employees; similarly, Faculty of Economics, Universitas Prof Dr Moestopo (Beragama), Indonesia expect it from its lecturers. Lecturers with good performance contribute to the advancement of the faculty better. However, this will only be achieved if the lecturers have a strong organizational commitment to the Faculty. The transformational leadership style can affect the commitment of the lecturers. When the leadership style is more oriented to the human resources than the tasks, the lecturers will feel that the faculty pays attention on them. Consequently, this will increase their commitment to the Faculty. Many leaders, however, still put more emphasis on the tasks, jobs, and productivity. They are not aware that lecturers as employees responsible for the production are actually an asset that should be empowered so that their contribution to the Faculty increases. In addition, interpersonal communication among faculty members and staffs will definitely affect lecturers' organizational commitment to the Faculty. Interpersonal communication may occur among lecturers and between lecturers and their superiors or faculty leaders. Should there be a good communication between faculty leaders and members, they will provide support to the faculty supervisors and managers. The support provided will generate commitment of the lecturers at the faculty. The real condition suggests that the majority of faculty leaders lack the ability to conduct interpersonal communication. This is due to the gap between the position of the leaders and the led.

Correspondingly, the lecturers' job satisfaction will affect their commitment to the organization. If they feel like receiving something from the faculty as expected, they get job satisfaction. Lecturers having job satisfaction will increase their commitment to the faculty. In fact, not all lecturers get job satisfaction. Satisfaction is not only determined by the amount of wages or salaries. Good-quality working environment is also a concern of the faculty. The working motivation of the lecturers will also affect their commitment to the organization. Lecturers, who are appreciated by the faculty or treated fairly, can improve their motivation. The increased working motivation of the lecturers will also enhance their commitment to the faculty. Motivation cannot be increased just by giving fair treatment to lecturers. They also need to be given challenges to improve productivity; hence, adequate incentives shall also be provided.

In the same way, confidence will affect lecturers' organizational commitment. If the faculty or the leaders give confidence to the lecturers, they would consequently put their trust on the leaders (faculty). On the contrary, excessive supervision to the lecturers will create an impression of a lack of confidence in them. Based on the aforementioned hypotheses, the study questions can be formulated as follows:

a. How far is the measurement result of the lecturers' organizational commitment at the Faculty of Economics, Universitas Prof Dr Moestopo (Beragama), Indonesia? 
b. How far is the contribution of operational value of transformational leadership style towards lecturers' organizational commitment at the Faculty of Economics, Universitas Prof Dr Moestopo (Beragama), Indonesia?

c. How far is the contribution of operational value of the interpersonal communication towards lecturers' organizational commitment at the Faculty of Economics, Universitas Prof Dr Moestopo (Beragama), Indonesia?

d. How far is the contribution of operational value of job satisfaction towards lecturers' organizational commitment at the Faculty of Economics, Universitas Prof Dr Moestopo (Beragama), Indonesia?

e. Is there any difference between the measurement results of several structured operational elements on the lecturers' organizational commitment at the Faculty of Economics, Universitas Prof Dr Moestopo (Beragama), Indonesia, and the direct measurement of the operational indicators of organizational commitment?

In this research, the result of measurement analysis, based on empirical data from various operational indicators, i.e.: transformational leadership style, interpersonal communication, and job satisfaction, will provide a clear representation of the organizational commitment of lecturers at the Faculty of Economics, Universitas Prof Dr Moestopo (Beragama), Indonesia.

The rest of this paper is organized as follow: Section 2 describes the notions of organizational commitment, transformational leadership, interpersonal communication and job satisfaction. Section 3 describes the proposed research framework and method. Section 4 presents obtained results and following by discussion. Finally, the conclusion of this work is described in Section 5.

\section{Rudimentary}

This section presents fundamental concepts of organizational commitment, transformational leadership, interpersonal communication and job satisfaction.

\subsection{Organizational Commitment}

The ideas of the experts on the definition of commitment vary widely. Some terms it as commitment, but others use the term organizational commitment. Basically, commitment is individual in nature; an attitude or behavior of an individual. The commitment of each individual to the organization where he works can be regarded as an organizational commitment. Ivancevich, et al. in [1] state that commitment is a feeling of identification, engagement, and loyalty expressed by workers towards the company. Thus, commitment concerns with three properties: (a) a feeling of identification with organizational objectives, (b) a feeling of being involved in the organizational tasks, and (c) a feeling of loyalty to the organization. According to Kreitner and Kinicki in [2], commitment is an agreement to do something for an individual, other individuals, groups or organizations; while the organizational commitment reflects the level of condition in which the individual identifies himself within the organization and get involved in its objectives. Meanwhile, Schermerhorn, et al. in [3] define commitment as an individual loyalty to the organization. Individuals with excellent organizational commitment strongly identify the organization and feel proud to consider them as a member.

Organizational commitment is defined as a willingness of some workers to remain a member of the organization [4]. Organizational commitment affects whether the workers remain as a member of the organization or leave the organization to look for a new job. In this case, turnover occurs. It is important to note that turnover can be done voluntarily or involuntarily. Voluntary turnover occurs when workers themselves decide to quit, whereas the involuntary turnover occurs when workers are fired by the organization for various reasons. Organizational commitment or employee loyalty is the degree to which employees identify the organization and want to continue to actively participate in it [5]. 
Organizational commitment is a measure of the desire of workers to remain in a company in the future. Commitment is strongly related and bound to the organization at an emotional level. It often reflects the trust of the workers in the mission and objectives of the company, the desire to develop business in its accomplishment, and the intention to continue working there. Commitment is usually stronger among long-term workers, those who have personal success experience in the organization and those who work in a committed group. Gibson, Ivancevich, et al. in [6] define organizational commitment as a feeling of identification, loyalty, and engagement expressed by workers towards the organization or unit within the organization. Thus, it can be concluded that organizational commitment is a feeling, attitudes, and behaviors of individuals to identify themselves as part of the organization, be involved in the activities of the organization, and be loyal to the organization to achieve the organizational goals. People pay attention to the work performance when they are committed to take action. An early detection on the lack of commitment will avoid problems in the future. Someone who feels uneasy to accept an agreement may not actually be committed.

There are a number of signs indicating that when a worker is committed to a task, his commitment can be either positive or negative. As a sign of a positive commitment, a worker shows enthusiasm, resolves issues, reports progress, and makes initiative. Meanwhile, as a sign of poor commitment, a worker submits a letter of resignation, ignores problems, keeps silent, and has lack of initiative [7]. Meanwhile, McShane and Von Glinow in [8] define organizational commitment as organizational loyalty. Factors that build organizational commitment include:

a. Justice and support; higher affective commitment occurs on the organization that fulfills its obligations to workers and stick to humanitarian values such as honesty, respect, willingness to forgive and moral integrity.

b. Shared values; affective commitment shows the identity of a person in the organization; the identification reaches the highest level when workers believe their values correspond to the dominant values of the organization.

c. Trust; this indicates positive expectations of one person against others in the situations involving risks. Trust means putting the fate of another person or group.

d. Organizational Comprehension; this shows how well employees understand the organization, including its strategic direction, social dynamics, and physical layout. This concern is an important prerequisite for affective commitment, because it is difficult to identify something with tools that we do not know properly.

e. Employee Involvement; this increases affective commitment by strengthening the social identity of the employee with the organization.

Based on these views, and by taking into account the condition of the researched object, the indicators of Organizational Commitment in this study include: (1) Enthusiasm, (2) Shared Value, (3) Trust, (4) Organizational Comprehension, and (5) Employee Involvement.

\subsection{Transformational Leadership}

The definitions of leadership are very diverse but not contradictory. Nevertheless, each can have a different viewpoint. Daft in [9] defines leadership as an ability to influence people towards the achievement of organizational goals. Definition of leadership according to Schermerhorn in [10] is the process of inspiring others to work hard to accomplish important tasks. While Yukl in [11] describes leadership as a process of influencing others to understand and agree on what needs to be done and how to do it, as well as the process of facilitating individual and collective efforts to achieve the common goals. Meanwhile, Newstrom in [5] defines leadership as the process of influencing and supporting others to work enthusiastically toward the achievement of goals. Essential elements within the definition are the influence/support, voluntary effort, and goal 
achievement. Colquitt, et al. in [4] describe leadership as the use of power and its influence to direct the activities of the members toward goals achievement. The directives may affect the members' interpretation of an incident, the management of work activities, commitment to the ultimate objectives, relationship among members, or access to the cooperation and support from other working units.

In the transformational leadership, the followers trust, admire, and appreciate the leaders. They are devoted and motivated to do more than expected; while the leaders transform and motivate the followers by (a) making them more aware of the importance of the tasks, (b) persuading them to improve their interest for the sake of the organization or team, and (c) enabling the needs to a higher level [11]. Moreover, a leadership style according Shermerhorn in [10] is the repetition of a pattern of behavior shown by a leader. Transformational leadership is inspirational. It generates tremendous efforts and performance. There are some indicators of transformational leadership style. A transformational leader has special qualities that can be the indicators as follows [10]:

a. Vision; having a clear idea and direction; communicating these ideas to others; building interest of completing the shared visions.

b. Charisma; using personal power and emotion, and evoking others' emotions, faith, loyalty, pride and confidence in the leaders.

c. Symbolism; identifying "heroes" and spontaneously organizing and planning ceremony to celebrate the excellence and great achievement.

d. Empowerment; helping others to thrive by eliminating the performance constraints, sharing responsibilities, and delegating challenging work.

e. Intellectual Stimulation; getting the involvement of other people by creating awareness of the problems and controlling their imagination.

f. Integrity; being honest and credible, acting consistently of private principles, and maintaining commitment.

Based on the opinion above, the transformational leadership style indicators used in this study are: (1) Creating a vision, (2) Integrity, (3) Communicating the charisma, (4) Empowerment, and (5) Encouraging learning.

\subsection{The Definition of Interpersonal Communication}

Communication is the process by which information and the meaning is transferred from the sender to the receiver [4]. Most of the works done in a team are resolved interdependently, mutually dependent, involving communication among members. Therefore, the effectiveness of communication plays a crucial role in determining whether there is a profit or loss in the communication process. Communication shows the process by which information is transmitted and understood by two or more people [8]. Emphasis on the words is understandable because it sends the intended meaning of the sender. This is the essence of good communication. It is the exchange of information between sender and receiver; it draws conclusion as the perception on a meaning of something between the individuals involved. Moreover, it can be said as the interpersonal exchange of information and understanding [2]. Likewise, communication is a process of sending and receiving symbols with a message attached to it [3-10]. Meanwhile, according to Greenberg and Baron in [12], it is the process by which people, groups or organizations as the sender send some types of information as a message or information to other person, group or other organization as the receiver. Thus, the synthesis taken is that, essentially, interpersonal communication is a process that shows the personal relationship between two parties in which the first party acts as a sender of a message to convey information to the second party as the recipient of the message to understand and respond.

The indicators of interpersonal communication can be seen from the way the communication is done i.e. through oral communication, written communication, or nonverbal communication [13]. 
a. Oral communication; the main vehicle to deliver message. This may be speech, individual or group discussions, and rumors.

b. Written communication; this is done through memos, letters, faxes, e-mail, instant messaging, periodical publications, warnings on bulletin boards, and other means conveyed through written words or symbols.

c. Non-verbal communication; in the verbal delivery of message, it is often followed by nonverbal messages. However, nonverbal component can also stand alone. The form can either be a glance, smile, frown, or gestures.

While Kreitner and Kinicki in [2] see the indicators of interpersonal communication in the form of how interpersonal communication style is conducted.

a. Assertiveness; in the communication is done by strongly pushing without attacking, allowing others to influence the results expressively. It includes self-improvement without forcing others.

b. Aggressiveness; is done by taking advantage of others; it is expressive and including self-improvement at the expense of others.

c. Non-assertiveness; is done by encouraging others to take advantage by preventing and breaking a promise.

d. Non-verbal communication; is the communication in which a message is delivered without the written word or speech, including the use of time and place, the distance between people in a conversation, the seating arrangements, the location, and office's furniture.

e. Active listening. Listening involves more than just hearing. Hearing is a physical component of listening. Listening is the process of actively decode and interpret verbal messages.

Founded upon the aforementioned opinions, interpersonal communication indicators used in this study include: (1) oral communication, (2) assertiveness, (3) aggressiveness, and (4) active listening.

\subsection{The Definition of Job Satisfaction}

The definition of job satisfaction lies on the emphasis of the respective viewpoints. These views are not contradictory, but complementary. Some state that job satisfaction is the level of pleasant feeling obtained from a person's job ratings or working experience [4]. In other words, job satisfaction reflects how we feel about our work and what we think about it. Robbins and Judge in [13] define job satisfaction as the positive feelings about work as the result of the evaluation of its characteristics. The job requires interaction with colleagues and superiors, follows the rules and organizational policies, meets the performance standards, and lives with less than ideal working conditions, and so forth; while McShane and Von Glinow in [8] see job satisfaction as an evaluation of a person in the context of job and working. It is someone's assessment of the characteristics, working environment, and emotional experience of a job. Another opinion suggests that job satisfaction is the affective or emotional responses to various aspects of a person's work [2]. This definition indirectly implies that job satisfaction is not a single concept. However, people are relatively satisfied with one aspect of their jobs and not satisfied with one or more aspects.

Based on the aforementioned opinions, a synthetic sense of job satisfaction can be formulated. Basically, job satisfaction is the level of pleasant feeling of someone as a positive assessment of his work, the work place environment, and emotional experience. Colquitt, Lepine, and Wesson in [4] describe two elements contained in the job satisfaction, i.e.:

a. Value fulfillment. In general, workers are satisfied if their jobs give something they value. Something valuable is everything that consciously or unconsciously people want to find or get to. 
b. Satisfaction with the work itself. Scientific management focuses on improving the efficiency of the tasks by making it more simplified and specialized. This step is expected to increase worker's productivity and decrease the number of types of skills needed to complete the job.

Meanwhile, according to Kreitner and Kinicki in [2], the elements that generate job satisfaction are:

a. Need fulfillment. Satisfaction is determined by the degree to which the characteristics of a job allow the individuals to meet their needs.

b. Discrepancies. Satisfaction is the results of the fulfillment of expectations reflecting the differences between what is expected to be received by an individual from his work, and what is actually received.

c. Value attainment. Satisfaction is the results of the perception that a job allows the fulfillment of the important working values of an individual.

d. Equity. Satisfaction is a function of how honest the workers are treated at work. It is the result of a person's perception that the relative work on the input is more fun than other significant result/inputs.

e. Dispositional/generic components. Job satisfaction is partly a function of personal traits and genetic factors.

Meanwhile, Schermerhorn, et al. in [3] reveal the indicators of job satisfaction by referring to The Minnesota Satisfaction Questionnaire (MSI) and Job Descriptive Index (JDI). The indicators of job satisfaction according to MSQ include: (a) working condition, (b) chances for advancement, (c) freedom to use one's own judgment, (d) praise for doing a good job, and (e) feeling of accomplishment. Meanwhile, the indicators of job satisfaction according to JDI are: (a) the work itself, (b) quality of supervision, (c) relationship with coworkers, (d) the promotion opportunities, and (e) pay. Based on these views, several indicators of the elements considered essential in this study for the achievement of job satisfaction, including: (1) the job itself, (2) working conditions, (3) quality of supervision, (3) equity, (4) need fulfillment, and (5) chances for advancement.

\section{Proposed Framework and Methodology}

This section presents proposed framework and methodology

\subsection{Research Framework}

The analytical framework used is the application of "TEV" Quantitative Analysis Model [14]. In the research field, there are quite a lot of applications of analysis methods used as a model for solving problems. The common method is the quantitative analysis method using metric data (quantitative). However, quantitative analysis method for nonmetric data (qualitative, categorical) still has limited application. Based on this consideration, innovation is necessary to develop the approach using quantitative analysis method on non-metric data. Thus, although the underlying philosophy is not the result of a new idea, innovation/development of several models of solving problems that have been discovered earlier is still possible.

a. Decision tree; the application of hierarchy model (structural sections), which is an alternative branch of dispute resolution on the conditions faced by various thoughts.

b. Expected value; an approach in assessing each alternative of problem solving or every group of the subsidiary derivatives in the decision tree.

c. Delphi Method, a method used to help researchers in compiling optimal decision tree while assessing the importance of quantity on each branch of the alternative resolutions.

The principal discussions of addressing a problem as an approach of this analysis method are the Decision Tree and Expected Value, while Delphi Method is used as a 
method of the optimization of decision trees and weighting called "TEV" Quantitative Analysis Model (MAKTEV). The "TEV" Quantitative Analysis Model begins from the study of some models of problem solution application with qualitative data by quantitative application of completion method. Here are several application models for the problem solution meant; in which some of these models are a stimulant on the creation of "TEV" Quantitative Analysis Model.

a. The application of Analytic Hierarchy Process (AHP) model; a process for the assessment of each alternative branch of problem solving (criteria/variables) with a degree of preference reflected in the consistency matrix, deemed to contain nonoperational subjective value.

b. The application of Technology Achievement Index (TAI) model; used by the United Nations Development Program (UNDP) to measure the level of technological achievement of several countries in the world whose calculation results are probabilistic in determining the index assessment of every problem solving analysis branch (dimension) that is totally done by using the statistical average calculation.

c. The application of Global Competitiveness Index model; used by the World Economic Forum (WEF) in measuring global competitiveness of a country to provide a high level of prosperity for its citizens. The analysis method uses nonmetric data, which is the perception of the executives (Executive Opinion Survey) with a measuring scale of seven categories, and the calculation uses the statistical parameter with weighting calculation.

From the description above, this creates stimulant to make innovation by providing an element of a model that is capable of completing the gap called "TEV" Quantitative Analysis Model. To transform the qualitative problem into quantitative form requires an approach, therefore, "TEV" Quantitative Analysis Model exists to describe the object (qualitative) to be studied in a number of factors (or dimensions) by using decision tree method, where the set of the dimensions represents the object as one unit.

\subsection{Research Methodology}

\subsubsection{Research Design}

This research is classified as a descriptive research with qualitative and quantitative analysis. According to Sekaran in [15], a descriptive study is done to learn and explain the characteristics of the variables examined in certain situations. This study is also classified as a case study because the only subject observed is the organization of the Faculty of Economics, Universitas Prof Dr Moestopo (Beragama), Indonesia. The study emphasizes the data collection; therefore, the study design is included in the category of a survey design and the data collection method used is sampling method.

\subsubsection{Analysis Design}

The analysis design utilizes the approach of "TEV" Quantitative Analysis Model [14], then the initial stage is to make a decision tree design. The decision of tree design is based on the description of the study design described above, whose object of the study is the "Lecturers' Organizational Commitment". Afterwards, a hierarchical structure is made, starting from the pillars (dimension), i.e. Transformational Leadership Style, Interpersonal Communication, and Job Satisfaction; until the operational hierarchy (indicators) of each pillar. Figure 1 as follow depicts an illustration of a decision tree of Lecturers' Organizational Commitment arranged completely. 


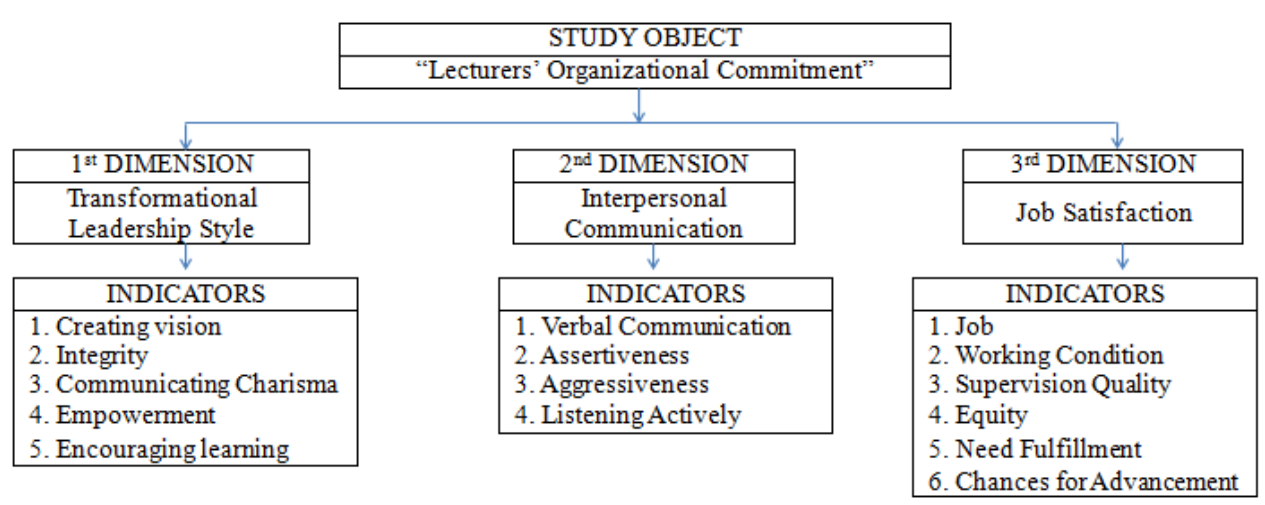

\section{Figure 1. Decision Tree of Lecturers' Organizational Commitment}

Each element of the decision tree in Figure 1 above in every group (dimension or indicator) should have respective weight. The formula to generate weight is as follows:

$$
A_{i}=\frac{\sum_{j=1}^{m} a_{i j}(m+1-j)}{\sum_{k=1}^{m} n k} ; \text { for } i=1,2,3, \ldots, m
$$

Where:

$A_{i}=$ Weight value of the i-element

$a_{i j}=$ The number of experts who assess Ai ranked as the $-\mathrm{j}$

$n=$ The total number of experts who perform the weighting

$m=$ The number of elements in the group of each branch of the decision tree

After all answers of respondents (lecturers) as the samples collected, then the calculation (assessment) was performed by using the formula of the expected value; the formula (2.2) is as follows:

Where:

$$
E V(X)=\sum_{i=1}^{n} k_{i} \quad p_{i}
$$

$X=$ Elements assessed, starting from the indicators, dimensions, up to the object

$P i=$ The weight of each element of the decision tree

$K i=$ Value of category (in the range of interval)

$N=$ The number of elements in the group of indicators and dimensions

\subsubsection{Sampling and Data Collection Methods}

A research with survey design focuses on data collection method or the sampling. Since the design of the study is a descriptive study, the number of samples required is 30 subjects [14]. Based on this provision, the amount of samples is set to be minimally 30 lecturers consisting of full-time and part-time lecturers. The method to obtain data in this study is through questionnaire, i.e. a list of written questions. 


\section{Results and Discussion}

This section present obtained results and following by discussion.

\subsection{Weight of Dimensions and Indicators}

The whole experts chosen to perform weighting the elements of the dimensions and indicators are amounted to 21 structural officials of Universitas Prof Dr Moestopo (Beragama), Indonesia. After weighting process, the results can be seen in Tables 1-4 below:

\section{Table 1. Weight of Dimensions}

\begin{tabular}{|l|l|l|}
\hline D14 $=$ EMPOWERMENT & \\
\hline D15 $=$ ENCOURAGING LEARNING & \\
\hline WEIGHT OF DIMENSIONS & \\
\hline D1 $=$ TRANSFORMATIONAL LEADERSHIP STYLE \\
\hline D2 $=$ INTERPERSONAL COMMUNICATION & \\
\hline D3 $=$ JOB SATISFACTION & \\
\hline & & \\
\hline
\end{tabular}

\section{Table 2. Indicators of Transformational Leadership Style}

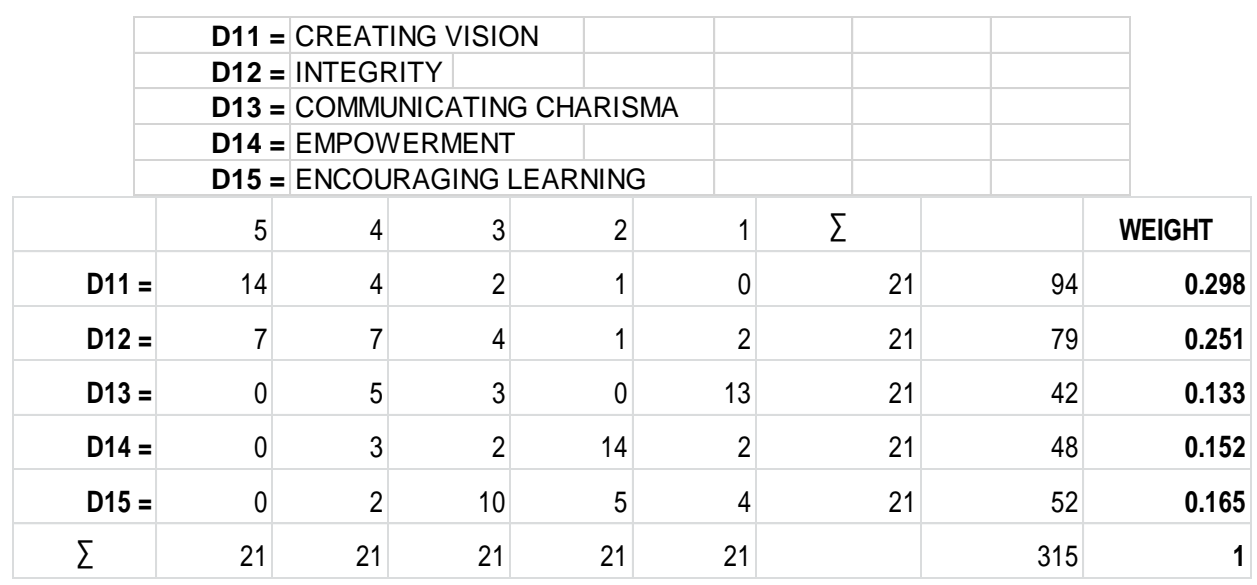

Table 3. Indicators of Interpersonal Communication
D21 = VERBAL COMMUNICATION
D22 $=$ ASSERTIVENESS
D23 = AGGRESSIVENESS
D24 = LISTENING ACTIVELY

\begin{tabular}{|c|c|c|c|c|c|c|c|}
\hline & 4 & 3 & 2 & 1 & $\Sigma$ & & WEIGHT \\
\hline D21 = & 7 & 8 & 4 & 2 & 21 & 62 & 0.295 \\
\hline $\mathrm{D} 22=$ & 12 & 1 & 7 & 1 & 21 & 66 & 0.314 \\
\hline $\mathrm{D} 23=$ & 0 & 3 & 3 & 15 & 21 & 30 & 0.143 \\
\hline D24 = & 2 & 9 & 7 & 3 & 21 & 52 & 0.248 \\
\hline$\Sigma$ & $21^{\prime \prime}$ & $21^{\prime \prime}$ & $21^{\prime}$ & 21 & & 210 & 1 \\
\hline
\end{tabular}




\section{Table 4. Indicators of Job Satisfaction:}

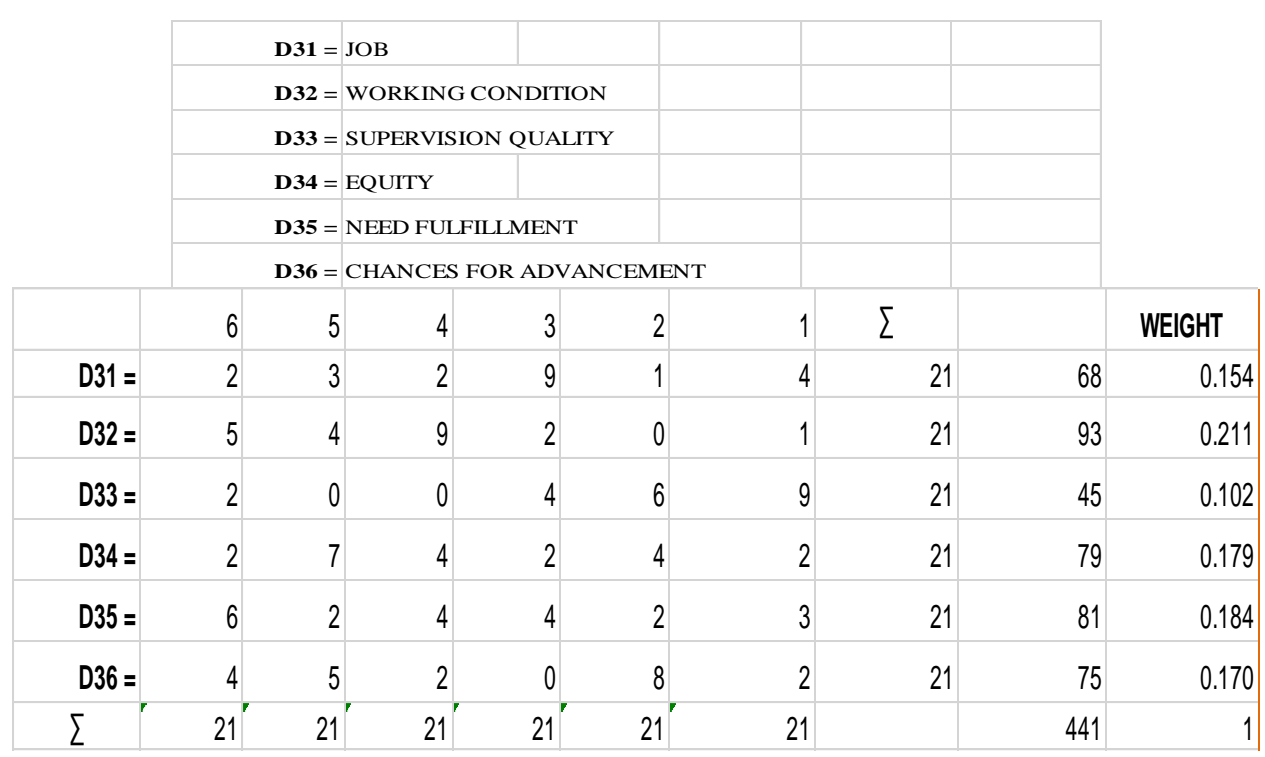

The weighting results indicate that in order to build the lecturers' organizational commitment at the Faculty of Economics, Universitas Prof Dr Moestopo (Beragama), Indonesia, the most important dimension is the Job Satisfaction in the organization, weighted of $36.5 \%$. In the second place is the dimension of the Interpersonal Communication with a weight value of $32.5 \%$, followed by Transformational Leadership Style as the last dimension in order to build "Lecturers' Organizational Commitment at the Faculty of Economics, Universitas Prof Dr Moestopo (Beragama), Indonesia" with a weight value of $31 \%$. This means that the Transformational Leadership Style has the lowest interest rate among other dimensions. On the contrary, Job Satisfaction is the most important dimension.

\subsection{Operational Value of Indicator}

There are 30 lecturers as the respondents, consisting of $56.7 \%$ of full-time lecturers and $43.3 \%$ of part-time lecturers. This means that perception is influenced by $56.7 \%$ of fulltime lecturers. Once the entire perception of the lecturers represented in the questionnaire (statements) spread to various points of declaration (measuring parameters) of any related indicators, the following analysis will generate value calculation of each indicator of each dimension. The overview of the value of each indicator calculation results can be seen in Tables 5-22 below:

\section{Table 5. Indicator of Transformational Leadership Style}

\begin{tabular}{|l|l|l|}
\hline D11 & $=$ CREATING VISION \\
\hline D12 & $=$ INTEGRIY \\
\hline D13 & $=$ COMMUNICATING CHARISMA \\
\hline D14 & $=$ EMPOWERMENT \\
\hline D15 & $=$ ENCOURAGING LEARNING \\
\hline
\end{tabular}

Where, D11: Creating Vision

1. Vice Dean and the Head of the Department have clear ideas of the ideals of the Faculty's future.

2. Vice Dean and Head of the Department can generate the interest of lecturers to support the ideals of the Faculty's future.

3. The views of vice Dean and the Head of the Department against the Faculty's future raise lecturers' enthusiasm and spirit. 
Table 6. The Value of the Calculation Result for Indicator D11

\begin{tabular}{|l|c|c|c|c|c|c|c|c|c|c|}
\hline D11 = & 3.489 & & SD & D & U & $A$ & SA & & \\
\hline & & 1 & 2 & 3 & 4 & 5 & $\Sigma$ & VALUE \\
\hline & & 2 & 3 & 10 & 8 & 7 & 30 & 3.500 \\
\hline 02 & 1 & 4 & 10 & 9 & 6 & 30 & 3.500 \\
\hline & & 03 & 1 & 7 & 7 & 7 & 8 & 30 & 3.467 \\
\hline
\end{tabular}

D12: Integrity

1. Vice Dean and Head of the Department act truthfully to the faculty staffs and lecturers.

2. Vice Dean and Head of the Department are being consistent to carry out what they have said.

Table 7. The Value of Calculation Result for Indicator D12

\begin{tabular}{|c|c|c|c|c|c|c|c|c|}
\hline D12= & 3.650 & & SD & $D$ & U & A & SA & \\
\hline & & & 1 & 2 & 3 & 4 & 5 & VALUE \\
\hline & & 01 & & 5 & 7 & 12 & 30 & 3.633 \\
\hline & & 02 & & 5 & 6 & 13 & 30 & 3.667 \\
\hline
\end{tabular}

D13: Communicating Charisma

1. Vice Dean and Head of the Department may influence lecturers to do what is expected by the faculty.

2. Vice Dean and the Head of the Department have the confidence to persuade lecturers to improve enthusiasm and spirit.

3. Vice Dean and the Head of the Department have personal strength to improve the motivation of the lecturers.

Table 8. The Value of Calculation Result for Indicator D13

\begin{tabular}{|r|r|r|r|r|r|r|r|r|}
\hline D13= 3.556 & & SD & D & U & A & SA & & \\
\hline & & 1 & 2 & 3 & 4 & 5 & VALUE \\
\hline & 01 & & 4 & 9 & 14 & 3 & 30 & 3.533 \\
\hline & 02 & & 3 & 11 & 9 & 7 & 30 & 3.667 \\
\hline & 03 & 1 & 4 & 11 & 8 & 6 & 30 & 3.467 \\
\hline
\end{tabular}

D14: Empowerment

1. Vice Dean and the Head of the Department entirely delegate the lecturers to make their own decisions in a specified task.

2. Vice Dean and the Head of the Department authorize the lecturers to take the necessary steps to overcome the problems as their responsibility.

\section{Table 9. The Value of Calculation Result for Indicator D14}

\begin{tabular}{|r|r|r|r|r|r|r|r|r|}
\hline D14 = & STS & TS & N & S & SS & & \\
\hline & & 1 & 2 & 3 & 4 & 5 & $\sum$ & VALUE \\
\hline & 01 & 1 & 2 & 6 & 11 & 10 & 30 & 3.900 \\
\hline & 02 & 3 & 1 & 3 & 15 & 8 & 30 & 3.800 \\
\hline
\end{tabular}

D15: Encouraging Learning

1. Vice Dean and the Head of the Department provide the opportunity for lecturers to learn about more up-to-date efficient method.

2. Vice Dean and the Head of the Department support the lecturers if they have opportunity for learning tasks. 
Table 10. The Value of Calculation Result for Indicator D15

\begin{tabular}{rrrrrrrrr|r|}
\hline$D 15=\quad 3.933$ & & $S D$ & $D$ & $U$ & $A$ & $S A$ & \\
\hline & & 1 & 2 & 3 & 4 & 5 & $\sum$ & \multicolumn{2}{l|}{ VALUE } \\
\hline & 01 & 1 & 2 & 5 & 11 & 11 & 30 & 3.967 \\
\hline & 02 & 1 & 2 & 6 & 11 & 10 & 30 & 3.900
\end{tabular}

Table 11. Indicator of Interpersonal Communication

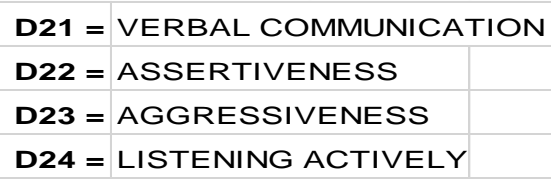

D21: Verbal Communication

1. Vice Dean and the Head of the Department submit tasks to be performed by lecturers verbally.

2. Lecturers discuss problems directly to the leaders of the faculty should there be any obstacles.

3. Discussion on personal issues can only be done by the lecturers during the break.

Table 12. The Value of Calculation Result for Indicator D21

\begin{tabular}{r|r|r|r|r|r|r|r|r|r|}
\hline D21 = & SD & D & U & A & SA & & \multicolumn{2}{l|}{} \\
\hline & & 1 & 2 & 3 & 4 & 5 & $\Sigma$ & \multicolumn{2}{|l|}{ VALUE } \\
\hline & 01 & 2 & 4 & 10 & 12 & 2 & 30 & 3.267 \\
\hline & 02 & 2 & & 9 & 11 & 8 & 30 & 3.767 \\
\hline & 03 & 3 & 4 & 9 & 11 & 3 & 30 & 3.233 \\
\hline
\end{tabular}

D22: Assertiveness

1. The Head of the Department sets specific target for lecturers.

2. The Head of the Department reprimands lecturers.

3. The Head of the Department takes action against lecturers who are not disciplined.

Table 13. The Value of Calculation Result for Indicator D22

\begin{tabular}{|c|c|c|c|c|c|c|c|c|c|}
\hline D22 = & 3.578 & & SD & D & U & A & SA & & \\
\hline & & & 1 & 2 & 3 & 4 & 5 & $\Sigma$ & VALUE \\
\hline & & 01 & & 5 & 7 & 13 & 5 & 30 & 3.600 \\
\hline & & 02 & & 3 & 14 & 8 & 5 & 30 & 3.500 \\
\hline & & 03 & & 3 & 11 & 10 & 6 & 30 & 3.633 \\
\hline
\end{tabular}

D23: Aggressiveness

1. The Head of the Department emphasizes earnestly on what should be resolved by the lecturers in time.

2. The Head of the Department provide incentives for lecturers who excel. 
Table 14. The Value of Calculation Result for Indicator D23

\begin{tabular}{|c|c|c|c|c|c|c|c|c|c|}
\hline D23 = & 3.750 & & SD & D & $U$ & A & SA & & \\
\hline & & & 1 & 2 & 3 & 4 & 5 & $\Sigma$ & VALUE \\
\hline & & 01 & & 3 & 7 & 12 & 8 & 30 & 3.833 \\
\hline & & 02 & 3 & 2 & 7 & 8 & 10 & 30 & 3.667 \\
\hline
\end{tabular}

D24: Listening Actively

1. Lecturers pay close attention to the instructions given by vice Dean and Head of the Department.

2. The Head of the Department is willing to listen to the lecturers' opinions related to the improvement of teaching and learning.

3. The vice Dean and Head of the Department consider the lecturers' opinions earnestly before making a decision.

Table 15. The Value of the Calculation Result for Indicator D24

\begin{tabular}{|r|r|r|r|r|r|r|r|r|}
\hline D24 = & SD & D & U & A & SA & & \multicolumn{2}{|c|}{ VALLE } \\
\hline & & 1 & 2 & 3 & 4 & 5 & $\sum$ & 3.767 \\
\hline & 01 & & 2 & 8 & 15 & 5 & 30 & 3.933 \\
\hline & 02 & & & 8 & 16 & 6 & 30 & 3.933 \\
\hline
\end{tabular}

Table 16. Indicator of Job Satisfaction

\begin{tabular}{|l|l|}
\hline D31 & $=$ JOB \\
\hline D32 & $=$ WORKING CONDITION \\
\hline D33 & $=$ SUPERVISION QUALITY \\
\hline D34 & $=$ EQUITY \\
\hline D35 & $=$ NEED FULFILLMENT \\
\hline D36 & $=$ CHANCES FOR ADVANCEMENT \\
\hline
\end{tabular}

D31: Job

1. The daily job is in accordance with the interests of lecturers.

2. Lecturers do specific works that can improve their productivity.

3. A profession as a lecturer is enjoyable because it is quite challenging.

Table 17. The Value of Calculation Result for Indicator D31

\begin{tabular}{|c|c|c|c|c|c|c|c|c|c|}
\hline \multirow{5}{*}{ D31 = } & 4.122 & & SD & D & U & A & SA & & \\
\hline & & & 1 & 2 & 3 & 4 & 5 & $\Sigma$ & VALUE \\
\hline & & 01 & & 1 & 5 & 16 & 8 & 30 & 4.033 \\
\hline & & 02 & & 3 & 5 & 13 & 9 & 30 & 3.933 \\
\hline & & 03 & & 1 & 2 & 11 & 16 & 30 & 4.400 \\
\hline
\end{tabular}

D32: Working condition

1. Physical environment of where the lecturers work is quite comfortable.

2. The working equipment provided in the workplace is suitable with the needs of teaching and learning in the right place at the right time.

3. The faculty pays attention on the availability of safety equipment of lecturers. 


\section{Table 18. The Value of Calculation Result for Indicator D32}

\begin{tabular}{r|r|r|r|r|r|r|r|r|r|r|}
\hline D32 = & & SD & D & U & A & SA & & \\
\hline & & & $\mathbf{1}$ & $\mathbf{2}$ & $\mathbf{3}$ & $\mathbf{4}$ & $\mathbf{5}$ & \multicolumn{2}{|c|}{ VALUE } \\
\hline & $\mathbf{0 1}$ & 3 & 8 & 11 & 6 & $\mathbf{2}$ & $\mathbf{3 0}$ & 2.867 \\
\hline & $\mathbf{0 2}$ & 1 & 4 & 11 & 10 & 4 & $\mathbf{3 0}$ & 3.400 \\
\hline & $\mathbf{0 3}$ & & $\mathbf{5}$ & 10 & 11 & 4 & $\mathbf{3 0}$ & 3.467 \\
\hline
\end{tabular}

D33: Supervision Quality

1. The vice Dean and Head of the Department provide guidance to the lecturers before starting to teach.

2. The vice Dean and Head of the Department make corrections to the lecturers if they make mistakes.

3. The vice Dean and Head of the Department ask the lecturers to train students if they have not been qualified

Table 19. The Value of the Calculation Result for Indicator D33

\begin{tabular}{r|r|r|r|r|r|r|r|r|r|}
\hline D33= & & SD & D & U & A & SA & & \\
\hline & & 1 & 2 & 3 & 4 & 5 & $\sum$ & \multicolumn{2}{l|}{ VALUE } \\
\hline & 01 & & 5 & 7 & 13 & 5 & 30 & 3.600 \\
\hline & 02 & & 2 & 12 & 14 & 2 & 30 & 3.533 \\
\hline & 03 & & 3 & 11 & 14 & 2 & 30 & 3.500 \\
\hline
\end{tabular}

D34: Equity

1. Each lecturer gets reward according to their performance.

2. The lecturers get a fair treatment from the faculty.

3. The vice Dean and Head of the Department are being truthful to all lecturers.

Table 20. The Value of the Calculation Result for Indicator D34

\begin{tabular}{|c|c|c|c|c|c|c|c|c|c|}
\hline D34 = & 3.611 & & SD & D & U & A & SA & & \\
\hline & & & 1 & 2 & 3 & 4 & 5 & $\Sigma$ & VALUE \\
\hline & & 01 & 2 & 5 & 7 & 9 & 7 & 30 & 3.467 \\
\hline & & 02 & 1 & 3 & 11 & 7 & 8 & 30 & 3.600 \\
\hline & & 03 & 1 & 1 & 11 & 8 & 9 & 30 & 3.767 \\
\hline
\end{tabular}

D35: Need Fulfillment

1. The lecturers' income is above the regional minimum wage.

2. The lecturers' income is sufficient to support their families.

Table 21. The Value of Calculation Result for Indicator D35

\begin{tabular}{|r|r|r|r|r|r|r|r|r|}
\hline D35 = & & SD & D & U & A & SA & \multicolumn{2}{|c|}{} \\
\hline & & 1 & 2 & 3 & 4 & 5 & $\sum$ & \multicolumn{2}{|l|}{ VALUE } \\
\hline & 01 & 5 & 2 & 14 & 2 & 7 & 30 & 3.133 \\
\hline & 02 & 5 & 9 & 10 & 1 & 5 & 30 & 2.733 \\
\hline
\end{tabular}

D36: Chances for Advancement

1. The vice Dean and Head of the Department assist lecturers to improve their necessary skills.

2. There are open opportunities for lecturers to gain promotion. 


\section{Table 22. The Value of Calculation Result for Indicator D36}

\begin{tabular}{|r|r|rrrrr|r|r|r|}
\hline D36 = 3.567 & SD & D & U & A & SA & & \\
\hline & 1 & 2 & 3 & 4 & 5 & $\sum$ & VALUE \\
\hline & 01 & 1 & 5 & 7 & 10 & 7 & 30 & 3.567 \\
\hline & 02 & 1 & 6 & 6 & 9 & 8 & 30 & 3.567 \\
\hline
\end{tabular}

All parameters of measurements (the points of statements) for each indicator of each dimension have obtained the results of the analysis; thus, the calculation as the final value is:

a. Transformational Leadership Style

The resulting weight value from experts' opinion is $0.310(31 \%)$

The calculated value from the perception of the lecturers is 3.667

Hence, the expected value is $(0.310)(3.667)=1.137$

b. Interpersonal Communication

The resulting weight value from experts' opinion is 0.325 (32.5\%)

The calculated value from the perception of the lecturers is 3.631

Hence, the expected value is $(0.325)(3.631)=1.180$

c. Job Satisfaction

The resulting weight value from experts' opinion is 0.365 (36.5\%)

The calculated value from the perception of the lecturers is 3.474

Hence, the expected value is $(0.365)(3.474)=1.268$

The value of the object of study on the "Lecturers' Organizational Commitment at the Faculty of Economics, Universitas Prof Dr Moestopo (Beragama), Indonesia", is computed as follow:

or in the category of "good".

$$
1.137+1.180+1.268=3.585
$$

The calculation of the expected value and the value of the weight of each indicator/dimension can be seen in Figure 2 below: 


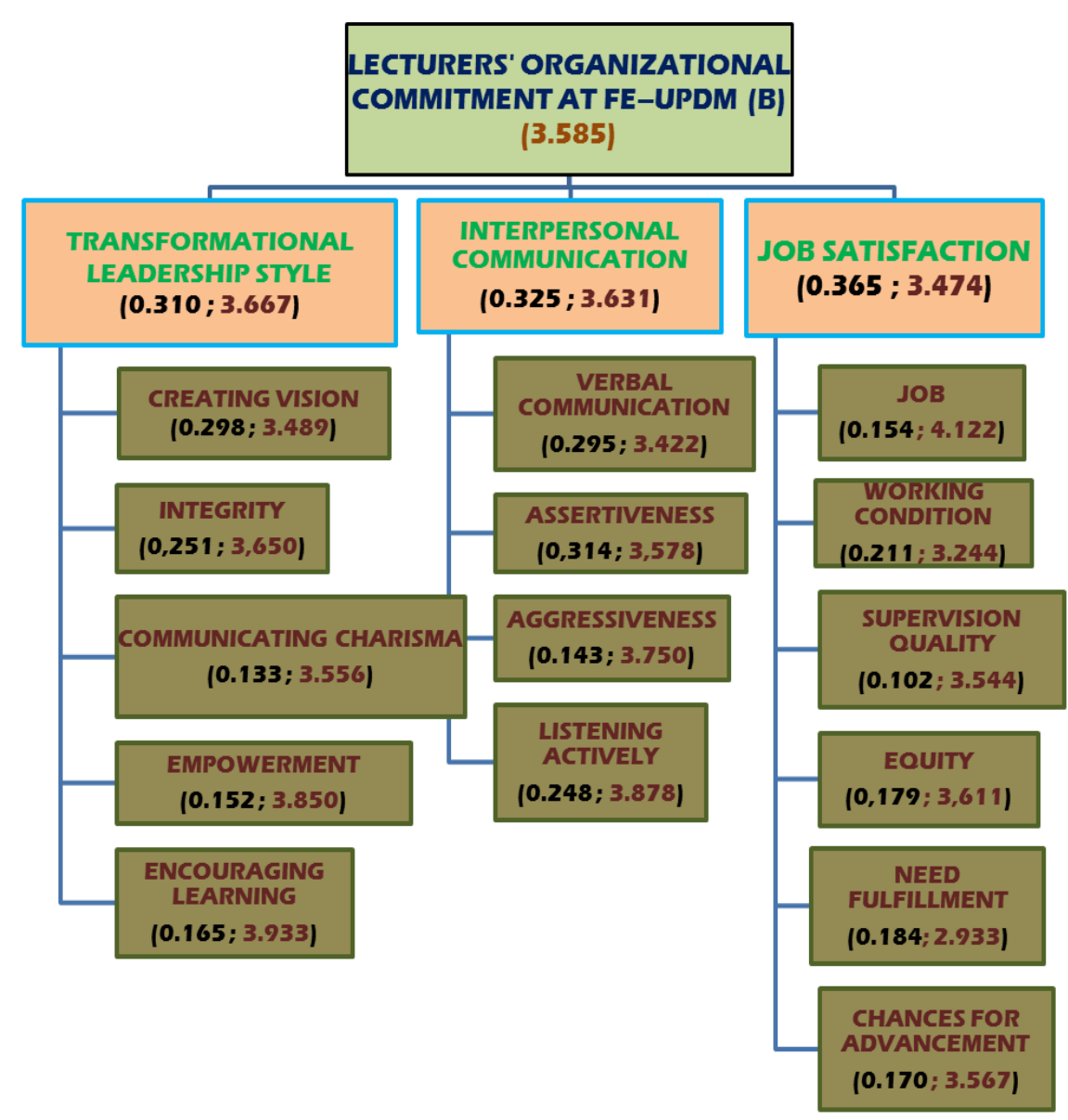

Figure 2. Calculation of Value in a Decision Tree

\subsection{Discussion}

The resulting value calculated from the analysis of the "Lecturers' Organizational Commitment at the Faculty of Economics, Universitas Prof Dr Moestopo (Beragama), Indonesia" is 3.585 or in "good" category. The organizational commitment in the body of the Faculty of Economics, Universitas Prof Dr Moestopo (Beragama), Indonesia shows that the performance in the process of the management of teaching and learning activities can be said in "good" category, but there are still more opportunities to improve the organization's ability to achieve excellent performance. The factor that become the focus of performance improvement is the dimension of object analysis, obtaining the lowest value, namely "Job Satisfaction" amounted to 3.474, followed by 3.667 for "Transformational Leadership Style" and 3.631 for "Interpersonal Communication". On the other hand, the weight of "Job Satisfaction" has the highest level of importance; that is 0.365 while for "Transformational Leadership Style" is 0.310 and 0.325 for "Interpersonal Communication". The description of these results suggests that the focuses of improving organizational performance of the Faculty of Economics, Universitas Prof Dr Moestopo (Beragama), Indonesia are the elements Job Satisfaction indicators.

\subsubsection{Job Satisfaction}

The serious effort to increase the performance capabilities of the Faculty of Economics, Universitas Prof Dr Moestopo (Beragama), Indonesia to achieve lecturers' organizational commitment in order to be included into the category of "very good" is to trace every 
indicator of Job Satisfaction which has the lowest value. Here is the composition of values of each indicator:

a. Job by 4.122

b. Working condition by 3.244

c. Supervision quality by 3.544

d. Equity by3.611

e. Need fulfillment by 2.933

f. Chances for advancement by 3.567

The value of the result analysis of each indicator of Job Satisfaction indicates that the value of the Need Fulfillment indicator, which is a top priority equal to 2.933 (the lowest score) needs to be considered. The elements of operational activities that should be improved are the measuring parameter value (statement points) of Need Fulfillment indicators, i.e.:

a. Is the lecturer's income sufficient to support a family? It is still being questioned, because according to the lecturer's perception, the value is 2.733 in the category of "moderate". The policy implication on the standpoint of lecturers still needs to be considered necessary.

b. Is the lecturer's income above regional minimum wage? It is still being questioned, because according to the lecturer's perception, the value is 3.133 in the category of "moderate". The policy implication on the standpoint of lecturers still needs to be considered necessary.

On the other side, the "job" indicator itself has been considered by the lecturers to be in the category of "good" with a value of 4.122. Likewise, the indicator of "Supervision Quality" has also come into the category of "good" with a value of 3.544. While for the other alternative, the indicator of "Working Condition" needs to be improved, since its highest weight of importance, according to expert, is $21.1 \%$ (a top priority to be considered). The resulting value of the analysis of "Working Condition" also shows the category of "moderate" with a value of 3.244.

The elements of operational activities that should be improved are the measuring parameter values (statement points) of "Working Condition" indicators, including:

a. Is the physical environment where the lecturers work comfortable? It is still being questioned, because according to the lecturer's perception, the value is 2.867 in the category of "moderate". The policy implication on the standpoint of lecturers is still needed to be considered necessary.

b. The working equipment is available in the right place at the right time according to the needs of teaching and learning. This is already considered approaching the category of "good" with a value of 3.400 , as for the value that has been included in the category of "good" starts from 3.410. It needs to be maintained, if necessary further enhanced periodically.

c. Faculty has considered the availability of safety equipment of lecturers. Its value is "good"; and should be maintained and even better if upgraded periodically.

\subsubsection{Transformational Leadership Style}

For a long-term policy in building commitment of the lecturers on the organization, in particular FE, Universitas Prof Dr Moestopo (Beragama), Indonesia, a trace from another dimension can be done, that is from the "Transformational Leadership Style". An effort to increase the performance capabilities of the Faculty of Economics, Universitas Prof Dr Moestopo (Beragama), Indonesia in the long term in order to remain able to maintain the category of "very good" is to trace every indicator of "Transformational Leadership Style" which has the lowest value. Here are the compositions of the value of each indicator:

a) Creating vision by 3.489

b) Integrity by 3.650 
c) Communicating charisma by 3.556

d) Empowerment by 3.850

e) Encouraging learning by 3.933

The resulting value of the analysis of each "Transformational Leadership Style" indicator shows that it has come into the category of "good". However, if the performance needs to be improved, the indicator of "Creating Vision" should be prioritized due to its lowest value. The review that should be done includes:

a. The view of the Vice Dean and Head of the Department on the future of the faculty improves the lecturers' enthusiasm and spirit. The value is "good"; maintained and even better if upgraded periodically.

b. The Vice Dean and Head of the Department have a clear idea of the ideals of the Faculty's future. The value is "good"; maintained and even better if upgraded periodically.

c. The Vice Dean and Head of the Department can generate the interest of lecturers to support the ideals of the faculty. The value is "good"; maintained and even better if upgraded periodically.

Operationally, the performance capabilities of "Creating Vision" can still be improved through three elements to make it included in the category of "very good".

\subsubsection{Interpersonal Communication}

Each indicator of the "Interpersonal Communication" traced has the lowest value. Here are the compositions of the value of each indicator:

a) Verbal Communication by 3.422

b) Assertiveness by 3.578

c) Aggressiveness by 3.750

d) Listening activelyby 3.878

Of the resulting values of each indicator analyzed, "Interpersonal Communication" entirely shows to be in the "good" category. However, the performance needs to be improved; the indicator of "Verbal Communication" should be prioritized due to its lowest value. The review that should be done includes:

a. Should the lecturers talk about personal problems during the break? This is still being questioned because according to lecturers' perception, its value is 3.233 in the category of "moderate". This means that there is still a private conversation by the lecturers during teaching hours. The policy implication is the certainty of regulation that lecturers could only make private conversations during the break.

b. Do the Vice Dean and Head of the Department submit tasks to be performed by lecturers verbally? This is still being questioned because according to lecturers' perception, its value is 3.267 in the category of "moderate". The policy implication is that the tasks for lecturers need to be reminded verbally by the leaders persuasively (for lecturers who need special attention).

c. Lecturers can discuss problems directly to the leaders if they find obstacles. The value is "good"; maintained and even better if upgraded periodically.

Those above are the tracing processes of elements of the decisions to be taken in the policy provisions in the future.

\subsubsection{Organizational Commitment}

The calculated resulting values of the indicators are traced directly from the variable of "Organizational Commitment" in order to complete more comprehensive policy implications on the research object of the "Lecturers' Commitment in the Organization of the Faculty of Economics, Universitas Prof Dr Moestopo (Beragama), Indonesia". Direct indicators of this variable consist of 5 (five) elements, namely: Enthusiasm, Shared Values, Trust, Organizational Understanding and Workers Engagement (See Table 23). 
Tables 24-28 presents the results of the analysis of the five elements of "Organizational Commitment".

Table 23. Five Elements of Organizational Commitment

\begin{tabular}{|l|l|l|}
\hline $\mathrm{K} 1$ & $=$ ENTHUSIASM & \\
\hline $\mathrm{K} 2$ & $=$ SHARED VALUES & \\
\hline $\mathrm{K} 3$ & $=$ TRUST & \\
\hline $\mathrm{K} 4=$ & ORGANIZATIONAL UNDERSTANDING \\
\hline $\mathrm{K} 5=$ WORKERS ENGAGEMENT & \\
\hline
\end{tabular}

After the analysis of the lecturers' perceptions data, the values of each indicator consist of:

K1: Enthusiasm

1. The faculty is excited to improve the quality of the alumni.

2. The faculty upgrades the technology to support the teaching and learning processes.

3. Lecturers are encouraged to follow the technological developments of the faculty.

Table 24. The Value of Calculation Result for Indicator K1

\begin{tabular}{|r|r|r|r|r|r|r|r|r|r|}
\hline K1 $=$ & 3.967 & & & & & & & \\
\hline & SD & D & U & A & SA & \multicolumn{2}{|c|}{ VALUE } \\
\hline & 1 & 2 & 3 & 4 & 5 & & \\
\hline 01 & & 3 & 6 & 11 & 10 & 30 & 3.933 \\
\hline 02 & & 2 & 6 & 12 & 10 & 30 & 4.000 \\
\hline 03 & & 3 & 3 & 16 & 8 & 30 & 3.967 \\
\hline
\end{tabular}

K2: Shared Values

1. The faculty introduces the values that need to be followed by lecturers as a member of the organization.

2. Lecturers tend to be adjusted to the values of the faculty.

3. Lecturers realize to be a part of the organization.

Table 25. The Value of Calculation Result for Indicator K2

\begin{tabular}{|r|r|r|r|r|r|r|r|r|r|r|}
\hline K2 $=$ & 3.856 & & & & & & \\
\hline & SD & D & U & A & SA & I & VALUE \\
\hline & 1 & 2 & 3 & 4 & 5 & & \\
\hline 01 & & 3 & 4 & 19 & 4 & 30 & 3.800 \\
\hline 02 & 1 & 4 & 6 & 13 & 6 & 30 & 3.633 \\
\hline
\end{tabular}

K3: Trust

1. Lecturers work jointly with mutual trust.

2. Faculty has confidence in lecturers' loyalty.

3. If the faculty puts trust in the lecturers, lecturers' trust to the faculty increases.

Table 26. The Value of Calculation Result for Indicator K3

\begin{tabular}{|c|c|c|c|c|c|c|c|c|}
\hline $\mathrm{K} 3=$ & 4.033 & & & & & & & \\
\hline & & SD & D & U & A & SA & $\Sigma$ & VALUE \\
\hline & & 1 & 2 & 3 & 4 & 5 & & \\
\hline & 01 & & 2 & 5 & 15 & 8 & 30 & 3.967 \\
\hline & 02 & & 1 & 4 & 18 & 7 & 30 & 4.033 \\
\hline & 03 & & 3 & 2 & 14 & 11 & 30 & 4.100 \\
\hline
\end{tabular}

K4: Organizational Understanding

1. Lecturers understand the strategic direction taken by the faculty. 
2. Faculty understands the importance of lecturers for the faculty.

3. The expectation of the faculty is clear upon the lecturers.

Table 27. The Value of Calculation Result for Indicator K4

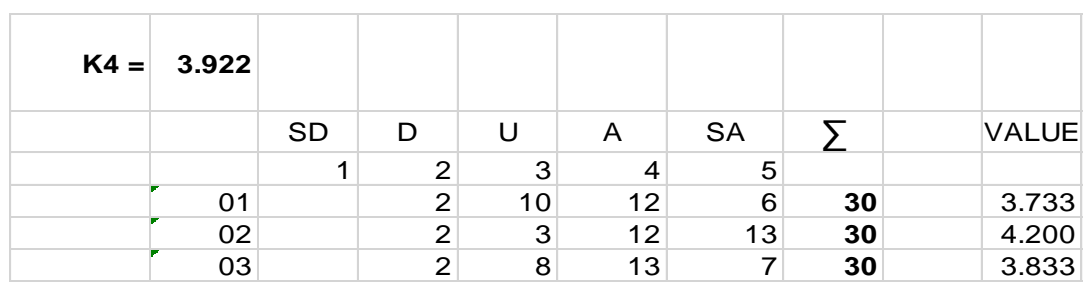

K5: Workers Engagement

1. Faculty provides opportunities for lecturers to give suggestions for the performance improvement.

2. Opinions of the lecturers are heard before the faculty makes decisions in the field of teaching.

3. The involvement of lecturers in the teaching and learning planning can enhance the commitment of the lecturers to the faculty.

Table 28. The Value of the Calculation Result for Indicator K5

\begin{tabular}{|c|c|c|c|c|c|c|c|c|}
\hline K5 = & 4.033 & & & & & & & \\
\hline & & SD & $D$ & U & A & SA & $\Sigma$ & VALUE \\
\hline & & 1 & 2 & 3 & 4 & 5 & & \\
\hline & 01 & & 1 & 6 & 11 & 12 & 30 & 4.133 \\
\hline & 02 & 1 & 1 & 7 & 14 & 7 & 30 & 3.833 \\
\hline & 03 & & 1 & 4 & 15 & 10 & 30 & 4.133 \\
\hline
\end{tabular}

All measuring parameters (statement points) of each indicator have obtained analysis results, so that after the analysis of average calculation statistically conducted, the final measured value of the research object can be generated, that is $\mathbf{3 . 9 6 2}$ of the "Organizational Commitment" (mean values of K1, K2, K3, K4 and K5) or in the category of "good". There is almost no significant difference; however, this comparison instrument cannot be taken as the main tool for measurement, because this is only as an alternative instrument in supporting more comprehensive policy implications.

\subsection{Policy Implication}

Based on the analysis and discussion above, the implication of policy in maintaining the dynamics of the organization should be continued, despite the objective to achieve Organizational Commitment at the Faculty of Economics, Universitas Prof Dr Moestopo (Beragama), Indonesia has been obtained at the "good" category. The efforts are solely conducted to achieve better targets and at least to maintain the performance. The following proposed policies are related to the discussion of making a decision, with the expectation that the goal to achieve Organizational Commitment at the Faculty of Economics, Universitas Prof Dr Moestopo (Beragama), Indonesia will generate analysis value of "very good" category.

\subsubsection{Primary Policy}

Job satisfaction, as the focus of the policy priorities set and followed in order to improve the Organizational Commitment in the organization of the Faculty of Economics, Universitas Prof Dr Moestopo (Beragama), Indonesia, achieves "very good" category. 
The elements of operational activities becoming the basis for the policy implication include:

a. The lecturers' income needs to be reviewed for a follow-up effort. The lecturers consider that the teaching revenue cannot be said worthy enough to support the family. Thus, the policy implication is the best way, out of efforts outlined in the strategic plan of activities.

b. The lecturers' revenue should beat at least above the regional minimum wage. The policy implication is in the form of increasing lecturers' revenue as outlined in the strategic plans.

c. The lecturers' physical working environment is quite comfortable based on their perception. The policy implication is in the form of improving the physical environment to be more comfortable as outlined in the strategic plans.

\subsubsection{Supporting Policy}

To support the efforts to improve the performance related to the study object of "Organizational Commitment" at the organizational body of the Faculty of Economics, Universitas Prof Dr Moestopo (Beragama), Indonesia, in order to be able to accomplish the goals with the category of "very good", the considerations are needed on the policy implications from the other dimensions. The elements of operational activities which form the basis for the policy implications are:

a. Are the lecturers only allowed to discuss personal issues during the break? This is still being questioned because according to lecturers' perception, its value is 3.233 in the category of "moderate". This means that there is still a private conversation by the lecturers during teaching hours. The policy implication is the certainty of regulation that lecturers could only make private conversations during the break.

b. Do the Vice Dean and Head of the Department submit tasks to be performed by lecturers verbally? This is still being questioned because according to lecturers' perception, its value is 3.267 in the category of "moderate". The policy implication is that the tasks for lecturers need to be reminded verbally by the leaders persuasively (for lecturers who need special attention).

\section{Conclusion}

The object of this study is "Organizational Commitment" implemented at the organizational body of the Faculty of Economics, Universitas Prof Dr Moestopo (Beragama), Indonesia. This study is an attempt to explore the perceptions of lecturers as the researched subjects (respondents) involved to determine the extent to which the performance of the faculty has been done so far. The goals of the performance improvement of the organization of the Faculty of Economics, Universitas Prof Dr Moestopo (Beragama), Indonesia based on the "Organizational Commitment" are influenced by three dominant factors, namely: Transformational Leadership Styles, Interpersonal Communication, and Job Satisfaction. These three factors are the sources in extracting information that can be uploaded as a matter of policy implication for a performance improvement. The necessary information is the elements of operational activities that are considered to be affecting the low performance; in other words, the resulting value of the analysis is still in the category of "very poor" or at least the category of "moderate". The study result suggests that the "Organizational Commitment" engaged in the organizational mechanism of the Faculty of Economics, Universitas Prof Dr Moestopo (Beragama), Indonesia is in the category of "good" by $56.7 \%$ influenced by the full-time lecturers. The "good" predicate is generated from two similar measuring instruments, both, the main instrument and the supporting instrument (no significant difference). The measurement results still provide an opportunity for the organization of the Faculty of Economics, Universitas Prof Dr Moestopo (Beragama), Indonesia, should 
the commitment on the organizational dynamics always desire to achieve a better target. Several alternatives can be considered from the study results to improve "Organizational Commitment" performance for having the "very good" category. On the one hand, the variable of "Job Satisfaction" has the highest weight value from the experts that is $36.5 \%$; while the other weight is 31\% for "Transformational Leadership Style" and 32.5\% for "Interpersonal Communication". On the other hand, based on the perception of the lecturers at the operational level, "Job Satisfaction" actually has the lowest value, that is 3.474; while "Transformational Leadership Style" gets 3.667, and 3.631 for "Interpersonal Communication". Based on these results, then the policy implications can be focused on the variable of "Job Satisfaction" with the operational activities that still do not get the value calculation results in the "good" category.

\section{Acknowledgement}

This research is supported by Universitas Teknologi Yogyakarta, Indonesia.

\section{References}

[1] Ivancevich, J.M., Robert, K., and Michael T. M. 2008. Organizational Behavior and Management. New York: McGraw-Hill.

[2] Kreitner, R. and Angelo, K. 2010. Organizational Behavior. New York: McGraw-Hill Companies, Inc.

[3] Schermerhorn, Jr. J.R., James G. H., Richard N. O., and Uhl-Bien, M. 2011. Ohio University. New York: John Wiley \& Sons, Inc.

[4] Colquitt, J.A., Jeffery A. L.P., and Michael J.W. 2011. Organizational Behavior. New York: McGrawHill Companies, Inc.

[5] Newstrom, J.W. 2002. Organizational Behavior: Human Behavior at Work. New York: McGraw-Hill Companies, Inc.

[6] Gibson, James L., John M. Ivancevich, James H. Donnelly, and Robert Konopaske. 2012. Organizations: Behavior, Structure, Processes. New York: McGraw-Hill Companies, Inc.

[7] Landon, K. and Christina, O. 2010. Performance Review. New York: Dorling Kindersley Publishing, Inc.

[8] McShane, S.L., and Glinow, M.A.V. 2010. Organization Behavior. New York: McGra-Hill.

[9] Daft, R.L. 1979. New Era of Management. Canada: South-Western Engage Learning.

[10] Schermerhorn, J.R. 2010. Introduction to Management. New York: John Wiley \& Sons, Inc.

[11] Yukl, G. 2010. Leadership in Organizations. New Jersey: Pearson Education, Inc.

[12] Greenberg, Jerald and Robert A. Baron. 2003. Behavior in Organizations. Upper Saddle River, New Jersey: Pearson Education, Inc.

[13] Robbins, S.P. and Timothy, A.J. 2011. Organizational Behavior. New Jersey: Pearson Education, Inc.

[14] Puguh, S. 2010. Model Analisis Kuantitatif “TEV”. Jakarta: PT. Indeks.

[15] Uma, S. 2006. Research Methods for Business: Metodologi Penelitian untuk Bisnis. Jakarta: Penerbit Salemba Empat. Book 1, Fourth Edition.

[16] Wibowo. 2013. Perilaku dalam Organisasi. Jakarta: PT Raja Grafindo Persada.

[17] Luthans, F. 2011. Organizational Behavior. New York: McGraw-Hill Companies, Inc.

[18] Newstrom, J.W. 2011.Organizational Behavior: Human Behavior at Work. New York: McGraw-Hill Companies, Inc.

[19] Gibson, J.L., John, M.I., James, H.D., and Rober, K. 2012. Organizations: Behavior, Structure, Processes. New York: McGraw-Hill Companies, Inc.

[20] Fornell, C. and Bookstein, F. 1982. Two Structural Equation Models: LISREL and PLS Applied to Consumer Exit-Voice Theory. Journal Marketing Research, 19.440-452.

[21] Ghozali, I.2008. Model Persamaan Struktural Konsep dan Aplikasi dengan Program Amos 16.0. Semarang: Badan Penerbit UNDIP.

[22] Puguh, S. 2009. Metode Penelitian Kuantitatif untuk Bisnis: Pendekatan Filosofi dan Praktis. Jakarta: PT. Indeks.

[23] Robbins, S.P. 2003.Organizational Behavior. New Jersey: Prentice Hall.

[24] Sugiyono. 2003. Statistik untuk Penelitian.Third Edition. Bandung: Alfabeta.

[25] Sugiyono. 2004. Statistik untuk Penelitian. Sixth Edition. Bandung: Alfabeta.

[26] Sugiyono. 2007. Metode Penelitian Bisnis. Bandung: Alfabeta. 
International Journal of Multimedia and Ubiquitous Engineering Vol.12, No.4 (2017) 